standard treatment of kidney failure and that proper funding should be made available through the NHS.

1 Winearls CG, Oliver DO, Pippard MJ, Reid G, Downing MR, Cotes PM. Effect of human erythropoietin derived from recombinant DNA on the anaemia of patients maintained by chronic haemodialysis. Lancet 1986;ii $117-8$.

2 Eschbach JW, Egne JC, Downing MR, Browne JK, Adamson JW. Correction of the anemia of end-stage renal disease with recombinant human erythropoietin. NEngl f Med 1987;316:73-8.

3 Sinai-Trieman L, Salusky IB, Fine RN. Use of subcutaneous recombinan human erythropoietin in children undergoing continuous cycling peritoneal human erythropoietin in children

4 Eschbach JW, Kelly MR, Halet NR, Abells RI, Adamson M, Adamson JW. Treatment of the anemia of progressive renal failure with recombinan
(a) human erythropoietin. $N$ Engl F Med 1989;321:158-63.

5 Executive Committee of the Renal Association. Recommendations for the use of recombinant human erythropoietin in patients with renal failure. London: HMSO, 1990. (Department of Health Circular PL/CO (90).)

6 Canadian Erythropoietin Study Group. Association between recombinan human erythropoietin and quality of life and exercise capacity of patient receiving haemodialysis. BMF 1990;300:573-8.

7 Casati S, Passerini P, Campise MR. Benefits and risks of protracted treatment with human recombinant erythropoietin in patients having haemodialysis. BMF 1987;295: 1017-20.

8 MacDougall IC, Lewis NP, Saunders MJ. Long term cardio-respiratory effects of amelioration of renal anaemia by erythropoietin. Lancet 1990;335: $489-93$.

9 Eschbach JW, Adamson JW. Recombinant erythropoietin. Implications for nephrology. Am f Kidney Dis 1988;11:203-9.

10 Gabriel R. Picking up the tab for erythropoietin. BMf 1991;302:248-9.

11 Taylor J, Henderson IS, Mactier RA, Stewart WK. Erythropoietin with drawal. BM7 1991;302:272-3.

12 Macdougall IC, Hulton RD, Cavill I, Coles GA, Williams JD. Treating renal anaemia with recombinant human erythropoietin: practical guidelines and a anaemia with recombinant human erythropo

13 Pollok M, Bommer J, Gurland HJ, Koch KM, Schoeppe W, Scigalla P, et al. Effects of recombinant human erythropoietin treatment in endstage renal Effects of recombinant human erythropoietin tre
failure patients. Contrib Nephrol 1989;76:201-11.

14 Leese B, Hutton J, Maynard A. The costs and benefits of the use of erythropoietin in the treatment of anaemia arising from chronic renal failure: a European study. York: Centre for Health Economics, University of York, 1991

15 Rosser R, Kind P. A scale of valuation of state of illness. Int $f$ Epidemiol 1978;7:347-58.

16 Eschbach JW. The anemia of chronic renal failure: pathophysiology and the effects of recombinant erythropoietin. Kidney Int 1989;35:134-48.

17 Winearls CG. Erythropoietin. Nephrol Dial Transplant 1989;4:323-6.

18 Bommer J, Ritz E, Weinrich T, Bommer G, Ziegler T. Subcutaneous erythropoietin. Lancet 1988;ii:406.

19 Stevens JM, Strong CA, Oliver DO, Winearls CG, Cotes PM. Subcutaneous erythropoietin and peritoneal dialysis. Lancet 1989;i:1388-9.

\title{
Mysterious slapped face rash at holiday centre
}

\author{
D J Gunnell
}

Abstract

Objective-To discover the cause of an outbreak of facial rash in a holiday centre.

Design-Questionnaire survey of those with rash; analysis of samples of linen.

Setting-Holiday centre in south west England.

Patients -98 holidaymakers presenting to the first aid post with a facial rash.

Intervention-Replacement of bed linen with new linen in selected parts of the site.

Results-The attack rate was $7 \cdot 0-14 \cdot 2 / 1000$ for most accommodation areas in the centre, but in one accommodation area the rate was zero. The $\mathrm{pH}$ of rinse water from sheets varied from $7 \cdot 4$ to $9 \cdot 0$. Those parts of the accommodation provided with new linen had zero attack rates.

Conclusion-The facial rash resulted from irritation from washing powder retained owing to insufficient rinsing during laundering. Modifications to the rinsing process led to a gradual disappearance of the rash.

\section{Introduction}

In March 1991 Somerset Health Authority's department of public health was informed by the local district council's department of environmental health of a mysterious "slapped face" rash at one of the holiday sites in its district. Investigations into the cause of the rash had been inconclusive; an infective cause, parvovirus infection (erythema infectiosum or slapped cheek disease), was suggested by local general practitioners and a dermatologist on the basis of appearance of the rash. Subsequent virological test results were negative and the epidemiology of the outbreak did not correspond to known infectious agents. No cases were reported in the local town by general practitioners. An allergen or irritant was thought the most likely cause for the rash, and a questionnaire survey was undertaken to identify the cause. The rash itself varied in severity from mild localised erythema on the cheeks alone to a more generalised erythema extending from the cheeks to the upper neck and ears. There was no scaling, weeping, or petechiae. The more severe rashes were pruritic and were slightly raised with an irregular margin. No pigmentation was left when the rash improved.

The centre at which the outbreak occurred can accommodate over 9500 guests. Some of the six main accommodation areas are self catering and others accommodate guests on half board. Soap and towels are not provided. The self catering accommodation is serviced by staff from the centre and outside contract staff before its occupation and thereafter by the customer. Half board accommodation is serviced daily by centre staff. Sheets and pillow cases in most rooms are provided by the centre. The site water supply is separate from that of the town; the centre obtains most of its food from a national supply depot, but some fresh food is obtained locally.

\section{Methods}

Cases were defined as all patients attending the first aid post complaining of a facial rash characterised by bright red cheeks or neck, or both, appearing as if the person had been slapped in the face. Cases were recorded by staff (registered general nurses and local general practitioners) at the first aid post.

Case notes were reviewed to determine the speed of onset of rash, the attack rate, and other characteristics of the illness. A register of all patients with rash was kept, recording name, age, chalet number, site of rash and associated features, date and time of arrival on site, and time of onset of rash.

Consecutive patients between 26 March and 6 April were surveyed by questionnaire to collect details of the use of the swimming pools, baths, and showers and source of food and drink consumed in the 24 hours before they attended for first aid. Serological testing for parvovirus and full blood counts were performed in several patients.

A controlled trial was performed. The site management purchased 250 new sheets and pillow cases and placed these in selected chalets. The new linen was then cleaned at a different laundry and reused for the next intake of guests in the same chalets. Results in the chalets with new sheets were compared with those in the other chalets.

The county analyst measured the $\mathrm{pH}$ of fixed 
quantities of water used to rinse individual sheets to assess residual alkalinity.

\section{Results}

Examination of case notes of those presenting with facial rash during one intake period identified 18 cases from 3174 guests, an attack rate of 5·7/1000. Ten of the patients presented within 24 hours, some within less than eight hours of arrival.

Serological tests for parvovirus had negative results in all cases and full blood counts showed an eosinophilia (over 4\% eosinophils) in five out of 10 patients. Eosinophilia is often found in allergic conditions such as asthma and hay fever, and it is also seen in drug reactions and in skin diseases such as eczema and psoriasis. Its presence was thought to indicate an allergic or irritant phenomenon; although it is known in parasitic conditions, it has not been documented in parvovirus infections. On the basis of these results and in conjunction with a review of cases the dermatologist made a revised diagnosis of irritant contact dermatitis.

Analysis of the questionnaire showed that some of the 98 people who developed the rash had neither eaten nor drunk anything on the site (15 and 7 respectively) and had not used the swimming pools (35) or taken a bath or shower (63).

The average age of the patients was $9 \cdot 8$ years and the average time from arrival to onset of the rash was 30 hours. No cases were reported in one area, in which $20 \%$ of guests were lodged; 21 cases would have been expected (table I). This accommodation area differed from the others in that it was cleaned by an outside firm of domestic cleaners and guests who stayed in it brought their own linen.

In view of the large number of cleaning materials used to prepare the rooms it was thought easier first to exclude the bed linen as the possible source of irritation. The controlled trial of new bed linen showed no cases of rash reported from the 500 beds supplied with new bedding, whereas the attack rate in the control areas was 56/1000 (135 cases among 2421 guests). We would have expected about 27 cases from the areas supplied with new linen as these were "school venture weeks." Children were more susceptible than adults in the centre, with attack rates peaking during these weeks, when large numbers of children stayed at the centre.

Further clues were sought from the ongoing register of cases (table II). This showed a higher attack rate during school venture weeks, with some cases occurring in clusters $(70 \%$ of one group of 30 children were affected). A low attack rate $(6 / 1000)$ in children was seen for the 23 February intake, when only three cases were seen in 2223 guests.

The county analyst reported that the $\mathrm{pH}$ of the rinse water from four sheets analysed was $7 \cdot 4,7 \cdot 8,8 \cdot 3$, and $9 \cdot 0$, suggesting variable retained alkalinity.

\section{Discussion}

The laundering process was clearly implicated by

TABLE I - No of cases of rash observed and expected, calculated by multiplying percentage of total guests staying in block by total number of cases

\begin{tabular}{lcccc}
\hline $\begin{array}{l}\text { Accommodation } \\
\text { area }\end{array}$ & $\begin{array}{c}\text { Total No } \\
\text { of guests }\end{array}$ & $\begin{array}{c}\text { Observed No } \\
\text { of cases } \\
\text { of rash }\end{array}$ & $\begin{array}{c}\text { Expected No } \\
\text { of cases } \\
\text { of rash }\end{array}$ & $\begin{array}{c}\text { Attack rate } \\
\text { (per 1000) }\end{array}$ \\
\hline A & 2649 & 0 & 20 & 0 \\
B & 2959 & 27 & 23 & $9 \cdot 1$ \\
C & 1975 & 25 & 15 & $12 \cdot 7$ \\
D & 1196 & 17 & 9 & $14 \cdot 2$ \\
E & 2005 & 14 & 15 & $7 \cdot 0$ \\
F & 2125 & 15 & 16 & $7 \cdot 1$ \\
\hline Total & 12909 & 98 & 98 & $7 \cdot 6$ \\
\hline
\end{tabular}

TABLE II-Attack rates

\begin{tabular}{lccc}
\hline & & \multicolumn{2}{c}{ Attack rate (per 1000 guests) } \\
\cline { 2 - 4 } Length of stay & & & $\begin{array}{c}\text { Children } \\
\text { aged 0-14 }\end{array}$ \\
\hline 15-18 February & 17 & $6 \cdot 5$ & $16 \cdot 2$ \\
18-22 February & 40 & $8 \cdot 9$ & $17 \cdot 1$ \\
23-25 February & 3 & $1 \cdot 3$ & $6 \cdot 3$ \\
01-04 March & 17 & $5 \cdot 0$ & $24 \cdot 3$ \\
08-11 March & 25 & $6 \cdot 9$ & $23 \cdot 4$ \\
11-15 March & 37 & $55 \cdot 2$ & $61 \cdot 0$ \\
19-24 March & 18 & $5 \cdot 7$ & $18 \cdot 9$ \\
26-30 March & 28 & $5 \cdot 5$ & $21 \cdot 9$ \\
01-06 April & 51 & $6 \cdot 4$ & $22 \cdot 2$ \\
06-11 April & 20 & $3 \cdot 0$ & $9 \cdot 0$ \\
15-19 April & 58 & $44 \cdot 0$ & $48 \cdot 9$ \\
19-22 April & 24 & $5 \cdot 5$ & Figures not \\
22-26 April & & & available \\
& 77 & $48 \cdot 0$ & $53 \cdot 3$ \\
\hline
\end{tabular}

$\star$ School venture weeks.

these results. As the linen from the centre went to a health authority laundry cases would have been expected from the hospitals it serviced, but inquiries in that district revealed no similar complaints.

The holiday centre's laundry went through the same large tunnel washer as laundry from the health authority. The machine, a Lavatrac 13 stage washer, represents the state of the art in modern, computerised machines and is used by other large laundries throughout the country. The laundry had used the same liquid detergent for three years, and this detergent had been in use elsewhere for longer with no reported similar problems.

Both the laundry and the detergent manufacturer felt that the evidence, although strong, was not conclusive; a mechanism by which only the laundry from the holiday centre was affected had to be sought. One significant difference between the holiday centre's laundry and the health authority's laundry is that the holiday centre uses cotton sheets and the health authority uses mainly polyester cotton sheets. Cotton is more likely to retain contaminants, thus offering a possible explanation of the lack of cases among the hospital patients.

Information on attack rates and in particular the low attack rate for the 23 February intake was taken to the laundry managers who, on inspecting their records, discovered that their main machine was out of action and a smaller tunnel washer had been used during this week. Also, the holiday centre's laundry was washed at a regular time in the evening, whereas hospital laundry was usually washed during the day. It was postulated that an intermittent fault, possibly related to lower water pressures in the evening, meant that batches of the evening laundry processed in the large tunnel machine were not being rinsed satisfactorily. This would explain the clustering of cases seen in some school groups, as the linen is stacked in batches as it leaves the machine. The linen returns to the centre in these batches and is then placed on the beds. Adjacent beds are therefore likely to receive linen from the same rinse batch.

Examination of the laundering process did indeed reveal problems with the water pressure regulator on the main tunnel washer. Repairs were started and in the meantime sodium bisulphite was added to the final rinse to neutralise any excess alkali. This, and temporary changes in the laundry company used, led to a disappearance of the rash.

Outbreaks of irritant contact dermatitis caused by bed linen have not previously been described. The irritation was thought to be caused by a combination of retained alkali in the linen, increasing the skin's permeability, and other substances in the detergent penetrating the damaged skin. Insufficient rinsing would have led to the detergent being retained in higher than usual concentrations. 
The county analyst's pH studies confirmed the presence of variable high levels of alkalinity, and the numbers of cases were reduced when a neutralising agent was added to the final rinse.

The detergent did not contain enzymes but among its 14 constituents was a low concentration of an optical brightener (Blankophor MBBH 766). Optical brighteners have been known to cause contact dermatitis. ${ }^{1}$ The detergent also contained caustic soda and potassium hydroxide, both of which are more likely to be retained in cotton than in polyester sheets.

The rash seemed to be irritant rather than allergic. This was suggested by the short time interval between arrival on the site and development of the rash (some appeared within eight hours). An attack rate of over $75 \%$ in some school parties also suggested a cause to which a high percentage of people were susceptible. Unlike allergic contact dermatitis, irritant dermatitis may affect all those exposed to the irritant-people's thresholds, however, may differ.

The commercial nature of the centre, with large groups of people (over 9500 at times) arriving and departing at intervals of three days to a week made rechallenging those in whom the rash developed difficult to coordinate. Atopy is known to predispose to irritant contact dermatitis; the questionnaire did not, however, request details of past atopy or allergy because at the time of the investigation the priority was to find a common causal link between cases.

The epidemic was brought to the attention of the health authority by the unusual situation of the holiday centre, with up to 9500 people sharing a common environment and 7000 sleeping in sheets laundered at a common source. The problem itself was of little medical significance but attracted disproportionate media attention, without which it may not have come to immediate medical attention. There were many possible sources for irritant allergic rashes. No previous problems had been reported with the detergent, and there were no cases of the rash in places whose laundry was processed by the same source, but these factors were misleading.

In the margarine disease in Holland in 1960 a slapped face rash was also originally mistaken for a viral infection; in this case emulsifiers in margarine were eventually found to be the cause. ${ }^{2}$ Thus food and drink were included in the questionnaire survey. Other known causes of contact irritant dermatitis were covered. Airborne agents have been shown to provoke an irritant dermatitis ${ }^{3}$ and so the sprays and cleaning materials used to clean the showers were considered. The irritancy of soaps has been described at length ${ }^{+5}$ and among other factors the $\mathrm{pH}$ is a significant cause of irritation. Malten suggested that once integrity of the surface of the skin had been severed, many substances and influences with minor degrees of aggressiveness could penetrate the skin and thus may add to deranging its metabolism. ${ }^{6}$ Alkaloids affect the lipids at the skin surface and dissolve water holding substances; keratin cross linkages are broken, and water penetration causes swelling of the horny layer. ${ }^{7}$ Contact irritant dermatitis from use of detergents and cleaners in the workplace has been described by Mathias, who lists soaps, detergents, and other industrial cleaners as the second commonest cause of occupationally acquired dermatitis in California. ${ }^{8}$ Published reports tend to suggest that younger people (with the exception of neonates) are no more vulnerable to the effects of irritants than are adults. ${ }^{910}$ Our series of patients suggests that this is not the case, with $90 \%$ of those affected being under 14 years of age. Further analysis of those affected may help determine a relation between irritant dermatitis, atopy, and sex.

I thank staff at the holiday centre and the Environmental Health Department of West Somerset District Council for their help in the investigation; Drs C Bowie, A Bussey, A Hill and A Morkane for their advice throughout the investigations; Dr C J W Guerrier for dermatological advice; and Mrs $M$ Beavil for typing the script.

1 Osmundsen PE. Contact dermatitis due to an optical whitener in washing powders. Br $\mathcal{F}$ Dermatol 1969;81:799-803.

2 Doeglas HMG, Hermans E, Huisman J. The margarine disease. Arch Dermato 1965;83:175-81.

3 Dooms-Goossens AE, Debusschere KM, Gevers DM, Dupré KM, Degreef $\mathrm{HJ}$, Loncke JP. Contact dermatitis caused by airborne agents. 7 Am Acad Dermatol 1986;15:1-10.

Strube DD, Nicoll G. The irritancy of soaps and syndets. Cutis 1987:39:544-5.

Rycroft $R$, Wilkinson J. The principal irritants and sensitizers. In: Rook A, Wilkinson D, Ebling $F$, Champion $R$, Burton J, eds. Textbook of

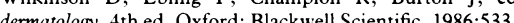

Malen KE. Thoughts on irritant contact dermatitis. Conact Dermatits 1981:7:238-47.

Ryect, R, Wilkinson J. Contact dermatis. In: Rook A, Wilkinson D,

Ebling F, Champion R, Burton J, eds. Textbook of Dermatology. 4th ed. Ebling F, Champion R, Burton J,

8 Mathias T. Contact dermatitis from use or misuse of soaps, detergents and cleaners in the workplace. Occupational Medicine 1986;1:205-18.

9 Kligmani AM. Cutaneous toxicology: an overview from the underside. Curren Problems in Dermatology 1978;7:1-25.

10 Harpin VA, Rutter N. Barrier properties of the newborn infant's skin F Paediatr 1983;102:419-25

(Accepted 11 November 1991$)$
Department of

Otolaryngology, University

Floor, Belfast City

Hospital, Belfast BT9 7AB

E J Stewart, FRCS, Allen and

Hanbury research registrar

$M$ J Cinnamond, FRCS,

professor of otolaryngology

Department of Respiratory Medicine, Royal Victoria

Hospital, Belfast BT12 6BA

R A Siddiqui, MRCP, senior house officer

D P Nicholls, MRCP,

consultant physician

C F Stanford, FRCP,

consultant physician

Correspondence to:

Dr C F Stanford, Wards

1 and 2, Royal Victoria

Hospital, Belfast BT12 6BA.

$B M \mathcal{F} 1992 ; 304: 479-80$

\section{Effect of a heat and moisture retaining mask on exercise induced asthma}

\section{E J Stewart, M J Cinnamond, R Siddiqui, D P Nicholls, C F Stanford}

Exercise induced asthma is less common during swimming than cycling or running, and the loss of heat and water is probably the stimulus to bronchoconstriction in susceptible subjects.' Avoiding rapid reheating after exercise also prevents this condition. An association between osmotic changes in bronchial epithelium and release of mediators from mast cells has been postulated. ${ }^{2}$ Currently, inhaled $\beta_{2}$ agonists or sodium cromoglycate administered before exercise are the preferred treatments, although good general control of asthma often reduces the incidence. We investigated whether using a mask that retains heat and moisture prevents the development of exercise induced asthma.

\section{Patients, methods, and results}

Four female and six male patients with asthma (age range 12-26) volunteered for the study. Their condition had been stable for several months, with symptoms being induced by exercise. No oral treatment was taken on the day of the exercise, and inhaled drugs were omitted for at least six hours. Patients were randomly allocated to exercise with or without a lightweight mask containing a filter that allowed exchange of heat and moisture (Filta Guard Mask, Intersurgical, Middlesex). The material of the filter is similar to that used in heat and moisture exchanges in intensive care. ${ }^{3}$ After 20 minutes of rest their forced expiratory volume in one second was measured. Exercise was performed on a cycle ergometer (three patients) or treadmill (seven) to achieve a pulse rate of $80 \%$ of maximum predicted values for age and sex. The forced expiratory volume in one second was measured immediately after exercise and then every four minutes for 20 minutes. The crossover arm of the study was performed on the same exercise machine during a second visit, which was at the same time of day and during the week after the first visit. The percentage 